\title{
A historiografia das migraçôes ultramarinas espanholas: Uma visão global
}

\author{
Xosé M. Núñez Seixas \\ Universidade de Santiago de Compostela
}

O objetivo deste artigo não é fazer uma análise exaustiva de todas e de cada uma das monografias sobre o tema das migrações, e particularmente sobre migração ultramarina, aparecidas na historiografia espanhola nos últimos anos. Como também não o é fazer um recenseamento pormenorizado de novidades e contribuiçóes bibliográficas. Dentre outros motivos, porque a extrema dispersão regional imperante na historiografia ibérica (não só espanhola, mas também portuguesa) faz com que tal empresa seja virtualmente irrealizável. Pelo contrário, objetivamos analisar algumas das principais tendências observáveis na historiografia sobre migrações hispânicas para a América no decurso da última década e, na medida do possível, situá-las no contexto mais global dos estudos migratórios. ${ }^{1}$

Inicialmente, para além disto, cabe advertir sobre um fato óbvio: os estudos de história das migrações na Espanha não constituem um oásis ou um compartimento estanque e ilhado da evolução e das tendências imperantes no conjunto da historiografia ibérica recente. Muitas das características definidoras, interpretaçōes e lacunas detectáveis também são atribuídas ao imputável na maior parte da historiografia (e outras ciências sociais) espanholas. Tem-se assinalado acertadamente que, para além do peso da pobre herança intelectual e universitária legada pelo longo regime franquista (1939-75), o mundo acadêmico da historiografia espanhola padece de alguns defeitos estruturais que não convidam à inovação. Dentre eles, destacam-se a obsessão pelas comemoraçôes e aniversários, a permanente atenção para os cantos de sereia dos poderes locais, e a relativa escassez de plataformas de discussão regulares. ${ }^{2}$ Como resultado disto, e da permanente miopia teórica da formação da maioria dos historiadores espanhóis, a historiografia hispânica, de maneira desigual, conforme os âmbitos temáticos, e com certo atraso na maior parte das vezes, continua devedora de tendências importadas de outras historiografias européias e norteamericanas. 
Este fenômeno é mais apreciável na medida em que os estudos migratórios, como campo interdisciplinar em que podem confluir focagens próprias da história social e política, da historia econômica, da antropologia social, da sociologia e da demografia (histórica ou não), estão pouco consolidados e carecem ainda de uma "marca de fábrica", de uma etiqueta definidora dentro da Academia espanhola.

Com a relativa exceção de alguns núcleos regionais/autônomos, pode-se afirmar que é possível aplicar aos estudos migratórios a conhecida metáfora das "mesas separadas" (separate tables) que utilizam os politólogos norteamericanos. ${ }^{3}$ Demógrafos, historiadores economistas, historiadores sociais e políticos, sociólogos e antropólogos estudam o tema migratório, mas com escasso diálogo entre eles. Mesmo no interior da corporação dos historiadores, pode-se observar, sem medo, o grau de exagero existente entre modernistas e contemporâneos, com o divórcio e a ignorância mútuos tendendo a predominar sobre a colaboração ou o enriquecimento recíproco que nasce do contraste de perspectivas. O mesmo acontece entre metodologias quantitativas e metodologias que colocam a ênfase na análise qualitativa; entre aqueles que depreciam o não numericamente quantificável e aqueles que ignoram as variáveis quantitativas.

Qualquer coisa semelhante costuma acontecer, com não demasiadas exceções, entre os historiadores contemporâneos e os hispanoamericanistas, cujas perspectivas de análise e questionamentos nem sempre coincidem com os dos dois grupos anteriores. O mesmo acontece, habitualmente, na hora de considerar não mais divisões entre épocas, mas entre campos temáticos. Uns ocupam-se principalmente da equação entre população e recursos e interessam-se fundamentalmente pelos fatores de saída ou de expulsão. Outros centram-se na análise de estatísticas de entradas e saídas de passageiros por mar. Outros ocupam-se preferencialmente das dinâmicas sociais de inserção socioprofissional nos países de acolhida, mediante métodos quantitativos e/ou qualitativos. Há, ainda, historiadores que preferem converter em objeto de análise as formas de articulação comunitária e associativa dos emigrantes, ou sua marca coletiva e individual na sociedade de origem. Poucos, ao contrário, são capazes de combinar todas as contribuiçôes de maneira autenticamente interdisciplinar e transtemática. E mais, é possível dizer que se ergue uma espécie de barreira invisível entre os especialistas em exílio e os especialistas em emigração. 
Os que se dedicam ao estudo do exílio republicano espanhol de 1939, provavelmente influenciados pelo predomínio quase esmagador das perspectivas típicas da história da literatura que dominam esse campo, apenas atentam para os debates que se estabelecem no campo dos estudos migratórios de caráter historiográfico ou sociológico, e raras vezes indagam acerca da interrelação existente entre imigrantes "econômicos" e exilados, e sobre as diferenças igualmente existentes entre ambos os grupos. ${ }^{4}$

Como já é conhecido, para o período anterior ao ano de 1992 - grande efeméride do Quinto Centenário da Descoberta da América - o atraso da historiografia e dos estudos migratórios hispânicos dentro do contexto internacional eram evidentes. Tratava-se de uma historiografia caracterizada por um marcado positivismo, um grande peso do que poderíamos denominar "paradigma hispanoamericanista tradicional" e pela ausência tanto de caráter interdisciplinar quanto de diálogo comparativo com outras historiografias migratórias, nomeadamente com a norteamericana, em parte pelo fato da emigração espanhola para os EE.UU. ter sido numericamente pouco relevante. Processo semelhante ocorria com a italiana, apesar da maior difusão da historiografia italiana na Espanha desde a década de 1980 ou, ainda, com as próprias historiografias migratórias dos países receptores de imigrantes espanhóis, várias das quais, como a argentina ou a mexicana, já tinham se desenvolvido antes de 1992. Em muitos casos tratavam-se ainda de crônicas, biografias e compilações de dados, mais do que de autênticos estudos monográficos.

Dentro de um panorama semidesértico, contudo, emergiam vários oásis, como bem mostra a compilação de estudos levada a cabo por Nicolás Sánchez Albornoz em 1988: Españoles en América, ${ }^{5}$ ou os primeiros trabalhos de uma nova geração de autores (Blanca Sánchez Alonso, César Yáñez, Alexandre Vázquez, Antonio Macías, Elda González, etcétera), consagrados plenamente na década de 1990.

Essa demora relativa, como, em 1993, já bem assinalava o historiador argentino das migrações Fernando Devoto, apresentava também algumas potencialidades de futuro, transformando, provavelmente, necessidade em virtude. Chegar por último, nesse sentido, comportaria algumas vantagens, pois permitiria selecionar o melhor das várias tradiçóes historiográficas e de estudos migratórios existentes, ser sabiamente ecléctico e evitar incorrer nos erros dos outros. Dentre esses erros evitáveis encontram-se, por exemplo, as divisões rígidas entre Idade Moderna e Contemporânea, o peso do paradigma neomalthusiano (desequilíbrio população-recursos), a 
excessiva ênfase na Labor History da historiografia migratória estadounidense, a acusada preferência pelo Estado-nação como quadro espacial das análises, e a escassa incidência relativa dos estudos baseados na análise de redes e em premissas microhistóricas. ${ }^{6}$ Características estas que, entretanto, não estão tão afastadas do assinalado por outros autores para o "estado da arte" dos estudos sobre a emigração italiana, que desfrutam de uma tradição mais presente e de um diálogo muito frutífero, principalmente, com a historiografia migratória norteamericana. ${ }^{7}$

Por volta dos anos 1992 e 1993, coincidindo com a comemoração do Quinto Centenário da Descoberta de América, foram publicadas dezenas de monografias, catálogos de exposições e realizaram-se alguns colóquios, contando com um generoso apoio institucional, tanto em escala estatal quanto autônoma e, por vezes, municipal. Resultado disso foram, por exemplo, a publicação de uma completa Historia General de la Emigración Española a Iberoamérica em dois volumes, ${ }^{8}$ cobrindo diversos eixos temáticos e, principalmente, a emigração de diversas regiōes ou Comunidades Autônomas que integram o Estado espanhol. Aliás, várias administrações autônomas promoveram publicações centradas nos aragoneses, nos bascos, nos andaluzes ou nos galegos na América, até completar-se o mapa autonômico instaurado em $1978 .{ }^{9}$ O tema migratório, graças a isto, atingiu maior visibilidade dentro da investigação histórica hispânica, em um campo temático - a presença de espanhóis na América, ou noutros destinos que até então tinha sido cultivado, principalmente, com referência ao exílio republicano de 1936-39. Algo perfeitamente compreensível na conjuntura política da Transição e na primeira fase da Consolidação Democrática espanhola (1975-82).

O legado dos festejos do Quinto Centenário da Descoberta da América em 1992 foi bem ambivalente. Certamente, em grande medida, tratou-se do que poderia ser chamado de "oportunidade perdida". Como bem tem assinalado Nuria Tabanera, ${ }^{10}$ multiplicou-se o número de monografias, incrementou-se notavelmente o volume de informação publicada sobre os espanhóis na América, avançou-se no conhecimento de parcelas temáticas e épocas cronológicas. Mas tudo foi feito, geralmente, de maneira caótica, reproduzindo os vícios teóricos e metodológicos da historiografia anterior, como a falta de questionamentos e uma pobreza teórica acompanhada de um positivismo estéril, tudo acentuado por uma regionalização - acrítica - dos marcos de análise, impostos pela nova estruturação territorial do Estado democrático espanhol desde $1978 .{ }^{11}$ 
Sem dúvida, foram dados passos significativos na direção de um maior diálogo interdisciplinar, de uma depuração e atualização de quadros teóricos de análise e de uma abertura para outras historiografias ou tradições de estudos migratórios. E mais, boa parte das monografias publicadas em 1992-93 com amplo apoio institucional e privado para comemorar o Quinto Centenário e a relação entre a Espanha e a América nem chegaram a tratar o tema migratório, centrando-se na contribuição de tal ou qual região à conquista e colonização da América na Idade Moderna, reproduzindo algumas delas prolixas revisitaçôes biográficas de missionários e conquistadores, de próhomens americanos de ascendência regional e da sua obra. ${ }^{12}$

Por outro lado, pode-se afirmar que, salvo exceçóes, as lacunas preexistentes reproduziram-se exponencialmente em pequena escala: um positivismo regional e local de novo cunho sucedeu ao já conhecido de escala estatal, com a agravante de que é habitual as monografias regionais ignorarem-se mutuamente. Isto obedece a uma concepção da História como disciplina e do próprio ofício de historiador, muito enraizada ao Sul dos Pirineus, embora, em absoluto, privativa da Península Ibérica: a consideração da investigação histórica e do quadro geral das ciências sociais como uma sorte de grande puzzle temático, um mosaico no qual a preferência é a de operar por acumulação de conhecimentos advindos de estudos de caso, delimitados territorialmente de maneira diversa e conforme as demarcações administrativas atuais.

Isto, contudo, não solucionaria o problema básico que, no fundo, segue afetando boa parte da produção historiográfica espanhola: um terrível ensimesmamento camuflado de positivismo local, e a falta de integração de perspectivas comparativas, dando lugar a uma multiplicação de monografias regionais e/ou locais que, por sua vez, apenas mostram preocupação em "colocar" problemas, por mais que se insista em apresentar as suas grandes virtudes de per se, como grãos de areia que contribuem para melhor conhecer feitos e fenômenos de maneira factual, sem perguntar-se o porquê do objeto de estudo regionalizar-se. Essa circunstância multiplicou-se na primeira década do século XX, quando, ao calor das facilidades para a pesquisa em temas regionais oferecidas por alguns Governos autônomos, o passado migratório de regiōes como Castela e León, La Rioja e mesmo da província de Zamora foi redescoberto, sem que as perspectivas analíticas tenham, minimamente, avançado. ${ }^{13}$

Esse ensimesmamento duplicado de positivismo, apesar de geral, afeta alguns campos da historiografia espanhola com mais intensidade do que 
outros. Um deles, em nossa opinião, é o hispanoamericanismo historiográfico, particularmente nos seus centros tradicionais (as universidades de Madrid e Sevilha, e o Consejo Superior de Investigaciones Científicas), embora sem desvalorizar os importantes avanços que acontecem nesse campo em outros núcleos, como o de Barcelona. ${ }^{14}$ Em primeiro lugar, porque os seus pressupostos teórico-metodológicos continuam muito ligados aos paradigmas clássicos da investigação em História Colonial, e a sua ampliação mecânica aos temas migratórios, tanto na Idade Moderna quanto na Contemporânea costuma ser problemática. Para colocar um exemplo, várias das monografias sobre a emigração de espanhóis para a América na época colonial continuam a limitar-se à exploração da documentação existente no Arquivo de Índias de Sevilha sobre o período colonial, procedendo a uma minuciosa análise estatística das listagens de passageiros, com as suas correspondentes distribuições por províncias e regiōes de origem. Contudo, apenas se abordam perguntas teóricas e questionamentos que ultrapassam essa mera reprodução de gráficas e tabelas. ${ }^{15}$

Para além disso, boa parte das monografias publicadas, muitas das quais provenientes da tradição de estudos baseados na Demografia Histórica ou na História Agrária modernista, obedeciam ao paradigma clássico da escola francesa dos Annales, que tem permanecido, de maneira quase imóvel, desde então: a preferência pelos modelos estruturais e holistas, que apenas conferiam capacidade de decisão e margem de eleição aos atores individuais, e que eram aplicados para detalhar os fatores de expulsão da emigração transoceânica. Estes e outros estudos costumam, portanto, insistir na já conhecida equação entre população e recursos como fator causal da emigração, com especial preferência e insistência nas crises agrárias e momentos de depressão econômica, más colheitas, etc., como desencadeantes imediatos de ondas migratórias e de movimentos de população. A isto, no caso de muitos historiadores da economia, adicionarse-ia um fator complementar: a análise do diferencial de salários e da presença ou ausência de industrialização na região ou comarca de origem. Tudo isto permitia configurar um grande puzzle de que saiam os saldos migratórios.

Este modelo geral, como já apontamos, tendia a ser reproduzido nas monografias regionais: os fatores de expulsão paradigmáticos explicavamse e eram expostos, em nível mesoterritorial ou microterritorial, sem maior reflexão posterior. Desta maneira, as possíveis vantagens da regionalização (o ter em consideração mais variáveis num âmbito 
manejável, o aprofundar no "olho da agulha" e no guardare piccolo para estudar melhor a multiplicidade de fatores que podem intervir no fato migratório) tenderam a diluir-se no paradigma geral. ${ }^{16}$ Em consequência, houve muito mais uma procura do miúdo, um cercare il piccolo, do que um olhar sutil, um guardare piccolo. Procuravam-se e encontravam-se numerosas minudências, mas não se adicionavam ingredientes às receitas já conhecidas. Em suma: apenas se analisava, com maior profundidade, uma escala reduzida. Com isto tudo, no fundo, tendia-se para uma lei de rendimentos decrescentes, neste caso aplicada ao âmbito historiográfico.

II.

O balanço de 1992 e suas seqüelas eram, desta maneira, tendencialmente pessimistas. Contudo, "não costuma haver mal que por bem não venha", ou, em outras palavras, tudo depende de se querer ver a "garrafa meio vazia ou meio cheia”. É indubitável, também, que alguma coisa ficou, apesar do refluxo orçamentário posterior a 1992-93 que, em boa medida, perdura até a atualidade.

De início, pode-se afirmar que a década de 1990 legou-nos uma série de monografias sólidas, tanto a nível estatal quanto regional, que marcaram algumas rotas novas e contribuíram para introduzir o assunto migratório nos debates mais contemporâneos de historia social e econômica, bem como na política espanhola da década de noventa. Por outro lado, algumas iniciativas de institucionalização dos estudos migratórios a nível regional apresentaram uma continuidade apreciável, como, de uma parte, os colóquios e monografias editadas pelo Archivo de Indianos de Colombres (Astúrias) até 1998-99; de outra, a constituição do denominado Arquivo da Emigración Galega no seio do Conselho da Cultura Galega (Santiago de Compostela), que, em 1997, publicou a primeira revista especializada em estudos migratórios na Espanha com vocação interdisciplinar: Estudos Migratorios, que continua, em uma nova etapa, co-editada em língua galega com a Universidade de Santiago de Compostela.

Para além disto, na segunda metade dos anos noventa, a vontade de construir algumas pontes de diálogo entre os enfoques historiográficos e sociológicas centradas no exílio republicano de 1939 ganhou visibilidade, bem como os fenômenos migratórios dos séculos XIX e XX. Fruto desse movimento, foi constituída a Asociación para el Estudio de las Migraciones y los Exilios Ibéricos (AEMIC) no ano de 1996, resultado da conjunção de historiadores dedicados ao estudo do exílio ibérico (antifranquista e 
antisalazarista, principalmente) na França - tradição consolidada no hispanismo francês e na Espanha e menos em Portugal, assim como alguns historiadores mais interessados nas migrações maciças do que no exílio de 1936-39. Um resultado da constituição dessa associação tem sido, até agora, a edição de duas revistas: a hispano-francesa Exils et Migrations Ibériques au XXe siècle, publicada pelo CIREMI da Universidade de Paris VII, que tem dedicado, até os dias de hoje, ao exílio do que às migrações, e a espanhola Exilios y Migraciones, nascida em 2000 e que já cumpriu dez anos de vida.

Ainda há muito caminho por percorrer, porém, na direção de uma certa concordância de critérios e na procura de um mínimo denominador comum de interesses entre a historiografia do exílio, por um lado, e dos estudos migratórios de índole historiográfica, por outro. Isto inclui a divergência entre focagens mais centradas na história social e política, as perspetivas de análise sociológica e antropológica, também preponderantes no estudo das migrações europeias (e da imigração na Espanha), e as aproximaçôes que abordam, principalmente, a produção literária sobre o exílio. Esses últimos privilegiam, é claro, o estudo da opinião publicada e das minorias de exilados (intelectuais, artistas e outros profissionais) que optaram por ligar seu nome às atividades criativas, para além da descrição (e por vezes análise) das atividades políticas dos exilados comprometidos com os seus partidos e organizações. Sua projeção ao conjunto de estudos históricos sobre o exílio leva igualmente à preponderância do que poderíamos denominar de paradigma de empatia emocional com o objeto de estudo que se traduz habitualmente na reprodução de biografias o prosopografias 'heróicas'. A reconstrução acrítica da memória dos exilados e a sua produção escrita, ou das suas biografias individualizadas, continua ainda a predominar sobre a análise das suas trajetórias sociais, da sua inserção socioprofissional ou da sua experiência coletiva. ${ }^{17}$

Certamente, alguns dos frutos positivos da colheita de 1992 que chegaram ao seu amadurecimento em meados da década de noventa, não têm tido muita continuidade. Depois da publicação da sua tese de doutoramento, no ano 1995, por exemplo, a historiadora econômica Blanca Sánchez Alonso apenas tem aprofundado ou diversificado os seus interesses e produção científica no tema migratório. ${ }^{18} \mathrm{O}$ relativo distanciamento do tema por parte de autores como o historiador chileno, radicado em Barcelona, César Yáñez Gallardo, que cultivou inicialmente a perspetiva macro e o enfoque estatístico, para passar, em seguida, a um frutífero 
enfoque mixto que combina, em nossa opinião, numerosas vantagens ao usar ambas as perspetivas, também parece indicar essa tendência. ${ }^{19}$

Com isto, os enfoques globais sobre a emigração espanhola para o ultramar têm perdido consistência, enquanto parecem ganhá-la, curiosamente, a investigação extra-hispânica sobre migrantes espanhóis na América ou em outros países, geralmente favorecida pela concentração do esforço investigador e do objeto de estudo na imigração espanhola em um determinado ponto de destino. Assim o confirmam as contribuições dadas, nesse sentido, por pesquisadores já consolidados, como José C. Moya, Alejandro Fernández ou M. Liliana Da Orden na Argentina, de Clara Lida, M. Cerutti, Tomás Pérez Vejo e outros autores no México, de Marília Klaumann de Cánovas no Brasil, ou de Carmen Norambuena no Chile; além da emergência de alguns novos autores e obras que vêm preencher alguns "vazios" temáticos nos países de destino, como acontece no caso de Costa Rica, Venezuela, Colômbia ou Peru. ${ }^{20}$

O enfoque "micro", de preferência regional, ou ainda centrado em um grupo étnico não-estatal, contudo, também abriu caminhos para a investigação histórica dos países receptores. Assim o demonstram, claramente, as monografias sobre os bascos em diferentes países, principiando pela Argentina, mas também as várias contribuiçōes sobre imigrantes galegos (na Argentina, no Uruguai ou no Brasil), ou catalães em distintos países. ${ }^{21}$ As escassas contribuições na historiografia hispânica, centradas no imigrante espanhol coletivo (no sentido genérico) em direção a algum país de destino, apareceram, com alguma e notória exceção, ${ }^{22}$ nos anos noventa. Nem, sempre, porém, direcionaram sua atenção para as contribuições da historiografia sobre a temática migratória dos países que estudavam, nem sequer no caso de volumes consagrados ao estudo da emigração espanhola nos Estados Unidos. ${ }^{23}$

$\mathrm{Na}$ segunda metade da década de noventa, não obstante, parece que teve lugar uma consolidação relativa, não tanto de uma única escola migratória hispânica, mas de vários focos ou núcleos regionais/autônomos que se centraram no estudo da emigração ultramarina, em parte europeia e interior, nas suas respectivas regióes. Dessa maneira, fizeram alguns esforços para introduzir-se em um quadro de análise mais amplo. Referimonos, em primeiro lugar, às já consolidadas escolas canária e galega. Junto a elas, mantém-se um significativo nível de produção e debate nas Astúrias e, notadamente, no País Basco e, tímidos, quase balbuciantes, existem, ainda, intentos de dar visibilidade ao tema migratório em outras zonas. Este pode ser o caso das Ilhas Baleares, ${ }^{24}$ onde a contribuição mais 
interessante até agora veio da Argentina. ${ }^{25}$ É o caso, também, de CastelaLeão, em especial, da província de Zamora, em que igualmente se registraram várias contribuiçōes de grande interesse, provenientes, de maneira muito especial, de pesquisadores argentinos interessados no olhar micro-histórico elaborado nessa província; da Rioja, e de Aragão, neste caso com base na tradição de história econômica regional.

a) O núcleo canário, a partir dos primeiros estudos de Julio Hernández García nas décadas de 1970 e $1980,{ }^{26}$ está representado, principalmente, pelas numerosas contribuições - infelizmente, muito dispersas em forma de artigos e contribuiçôes em congressos - do historiador da economia Antonio Macías e sua escola. ${ }^{27}$ Esta se tem centrado principalmente no estudo da emigração canária para Cuba e Venezuela nos séculos XIX e $\mathrm{XX}$, abrangendo tanto a saída quanto a viagem, a inserção sociotrabalhista nos pontos de destino e, em menor medida, o retorno da emigração. ${ }^{28}$ Dominada por um enfoque característico da História Econômica, com especial predileção pelo estudo de contingentes e remessas, neste caso com amplo e imaginativo uso de fontes fiscais, ${ }^{29}$ este enfoque fazia os fatores de saída dependerem, principalmente, das oscilações do mercado de trabalho e do diferencial de salários. É de destacar-se neste núcleo uma progressiva abertura para enfoques mais individualizados, centrados no estudo e análise de estratégias familiares e comunais, assim como das redes microssociais. ${ }^{30}$

b) $\mathrm{O}$ núcleo galego, dividido entre as três universidades da Galiza (Santiago de Compostela, Vigo a A Corunha), é possivelmente o que apresenta maior variedade temática, pois conta, dentre seus integrantes, com sociólogos, antropólogos, historiadores da educação, historiadores economistas, demógrafos, modernistas, contemporaneistas, latinoamericanistas e historiadores da literatura (galega e espanhola). Por detrás da proliferação de estudos sobre migração na Galiza da década de noventa está, sem dúvida, o fato de que quase em nenhuma região (ou nação) da Península Ibérica a emigração e as suas consequências adquiriram um peso tão determinante na evolução econômica, social, política e cultural global, em um continuum que vai das migraçôes peninsulares dos séculos XVII e XVIII até as transoceânicas de XVIII, XIX e XX.

Em sucessivas ondas, que alcançaram a década de 1960, essas migraçôes atingiram diferentes destinos (Argentina, Brasil, Uruguai, Cuba, México, EE.UU., Canadá, Venezuela, Europa central, Austrália, até alguns pontos da África), com consequências sociopolíticas e econômicas que continuam 
a ser perceptíveis na atualidade, como o demonstra a influência eleitoral dos mais de trezentos mil votantes galegos recenseados no exterior. Para além disso, o fato de Buenos Aires ter sido a cidade onde se concentrou grande número de exilados nacionalistas e republicanos galegos; ter sido a capital da Galiza livre durante a longa noite do franquismo e ter dado suporte aos movimentos sociopolíticos renovadores do país de origem ao longo do século $\mathrm{XX}$, através das comunidades de emigrantes galegos nas Américas, convertem também a emigração em um fator onipresente. Afinal, não há tema da historia econômica, social, cultural e política da Galiza em que as migrações não intervenham de maneira direta ou indireta, desde a evolução das estruturas agrárias até ao desenvolvimento dos distintos movimentos sociais renovadores (o agrarismo ou o movimento operário) ou do nacionalismo galego. A isto se soma, obviamente, a referida institucionalização dos estudos migratórios, assim como o aumento da quantidade e da qualidade das fontes disponíveis. ${ }^{31}$

Igualmente, no caso galego também intervém um outro fator: o interesse do Governo autônomo, em primeiro lugar, mas também de outros agentes sociais e políticos, principalmente da esquerda nacionalista e sindical, em manter a memória da emigração (com diferentes modulações e implicações) e criar, sobre a mesma, diversos mitos com interpretaçóes opostas. ${ }^{32}$ Isto constitui uma vantagem, mas implica também os seus riscos: o perigo de produzir em excesso para um mercado local e institucional que necessita mitos e reafirmação, mas que "devora" historiadores com sentido crítico e propicia, antes de mais nada, a ausência de discussão e o umbiguismo (isolacionismo) historiográfico mais cruel.

Embora a disparidade de interpretações e enfoques reproduza a escala mesoterritorial o fenômeno das separate tables já aludido para o caso espanhol global, em geral permite afirmar que dispomos de estudos satisfatórios, e, em alguns casos, exaustivos sobre os fatores de saida (push) e sobre as condições do transporte na época da emigração ultramarina maciça, ${ }^{33}$ sobre a obra socioeducativa dos emigrantes para a América, ${ }^{34}$ sobre a integração dos galegos em países como Uruguai, México, ou Porto Rico, e em contextos urbanos específicos como o Sul do Grande Buenos Aires ou a cidade de Rio de Janeiro, ${ }^{35}$ sobre as dinâmicas sociopolíticas do associativismo emigrante ou, ainda, sobre as consequências sociopolíticas da emigração. Há, também, abundantes silêncios sobre as migrações da Idade Moderna, peninsulares ou ultramarinas, ${ }^{36}$ uma importantíssima quantidade de estudos localizados sobre emigrantes galegos 
nos mais diversos pontos da América, cuja enumeração poupamos, e incipientes visões sintéticas sobre a imigração galega no país que mais acolheu imigrantes: a Argentina. ${ }^{37}$ Ao contrário, faltam ainda investigações de maior peso sobre a importante presença galega em países como a Venezuela. Igualmente, a diversidade temática é ampla, incluindo desde aspectos sociopolíticos até culturais e literários, ${ }^{38}$ passando pela abordagem da relação entre gênero e emigração. ${ }^{39}$ Possivelmente, - fora de algumas sínteses de divulgação - estamos ainda carentes de visões definitivas de conjunto, dada à rapidez com que estão evoluindo os nossos conhecimentos, e a diversidade de enfoques que se consolidaram no estudo das migrações galegas. ${ }^{40}$

c) O núcleo asturiano parece estar em vias de superar o certo refluxo observável em meados da década de noventa. Depois dos estudos, alguns deles já clássicos, que proporcionam uma apreciável imagem de conjunto da emigração asturiana para a América, principalmente por parte de Rafael Anes, ${ }^{41}$ ou o sumamente útil e pouco citado livro de Jesús Jerónimo Rodríguez, ${ }^{42}$ assim como outros estudos realizados nos últimos anos. Dentre estes, são de mencionar as afortunadas incursóes em tema migratório de historiadores especializados em história social da região (burguesia, vida quotidiana e movimento operário), como Francisco Erice, que tem desenvolvido o estudo da coletividade asturiana de Cuba e o impacto dos indianos na sociedade de origem depois de 1898; ou, em menor medida, o trabalho do antropólogo Juaco López Álvarez sobre o associativismo asturiano naquela ilha. ${ }^{43} \mathrm{~A}$ incipiente diversificação temática parece orientar-se preferencialmente à exploração dos ricos fundos epistolares e fotográficos privados. ${ }^{44}$

d) $\mathrm{O}$ núcleo basco-navarro tem adquirido um peso considerável em redor de vários historiadores americanistas da Universidade do País Basco (principalmente, Oscar Álvarez Gila e a sua incipiente escola, mas também de outros autores como Alberto Angulo ou Ana Zaballa). ${ }^{45}$ Este foco historiográfico mostra igualmente uma considerável diversidade temática desde a emigração basca na Idade Moderna à América até às migrações interiores de navarros e bascos à Península Ibérica, passando por temas como a participação basca na Igreja americana, o influxo do nacionalismo basco nas coletividades emigradas de América, ou as festas comunitárias dos bascos do Oeste dos Estados Unidos -, demonstrado, também, uma notável preocupação com o enriquecimento dos enfoques metodológico e teórico, manifestado no estudo das estratégias dos atores individuais e dos grupos familiares, construção de imaginários simbólicos, rituais e 
comemorações das comunidades de emigrantes bascos, e um longo etc. A isto adiciona-se o fato de que, sendo a região basca do lado francês uma área de forte emigração para a América, tanto do Norte coma do Sul, o caso basco converte-se num dos melhores laboratórios para investigar as dinâmicas transfronteiriças das migrações ultramarinas, os mecanismos de transmissão da informação e a articulação de cadeias migratórias nos dois lados da fronteira estatal. ${ }^{46}$ Complementa-se assim a preponderante atenção, mais no âmbito extra-acadêmico do que no acadêmico, que se outorgava ao tema do exílio basco (republicano e nacionalista) por ocasião da guerra civil, questão esta sobre a qual ainda há muito caminho por percorrer. ${ }^{47}$

e) Outros núcleos historiográficos regionais parecem estar em franca retração, como o catalão, antigamente mais ativo, com incursões locais sobre o tema das remessas, o impacto dos "indianos" (retornados) em algumas comarcas, a articulação das comunidades catalās na América, as redes comerciais dos catalães em Cuba, etc. Pelo contrário, as contribuiçõos de maior interesse desde as décadas finais do século XX provêm, em sua maior parte, de historiadores radicados em pontos de destino da emigração catalã, como o México ou a Argentina. ${ }^{48}$ Contudo, também é certo que uma importante produção historiográfica sobre o exílio catalão em geral e catalanista em particular sobrevive, embora muito centrada nos acontecimentos políticos em uma ótica descritiva. ${ }^{49}$ Alguma monografia publicada ultimamente sugere ainda que alguma coisa ficou daquela fermentação historiográfica. ${ }^{50}$

Um núcleo com relativa força, embora de dimensões reduzidas, é igualmente o da Cantábria (antiga província de Santander), principalmente graças aos trabalhos de Consuelo Soldevilla sobre emigração santanderina (cântabra) para a América, fruto em boa medida da regionalização da investigação histórica antes aludida, e que apresenta uma cuidadosa elaboração de fontes de natureza diversa, desde padrões municipais até testemunhos orais. ${ }^{51}$ Alguma coisa parecida se poderia afirmar do núcleo murciano (região de Múrcia, SE da Espanha), se bem que este último apresenta a particularidade de dedicar maior atenção aos destinos preferenciais da emigração levantina nos séculos XIX e XX e de ter abordado a emigração regional em direção ao Norte da África e, a partir desse exemplo, a emigração espanhola ao Norte do continente africano numa significativa síntese. ${ }^{52}$

f) Desde meados da primeira década do século XXI é de salientar a emergência relativa de dois núcleos de pesquisas regionais muito ativos. 
De um lado, o nucleado por várias iniciativas na província de Samora e que tem por objeto a recuperação da memória da emigração ultramarina dessa província em direção à América, de dimensões importantes em algumas das suas comarcas e com um modelo de difusão e destinos muito semelhantes aos da vizinha Galiza, se bem que, neste caso, é principalmente o interesse de vários pesquisadores dos países de destino o que mais contribui para renovar a nossa visão da emigração ultramarina nessa região. ${ }^{53}$ Por outro lado, o renovado interesse pelas migraçōes ultramarinas orientadas desde Aragão, onde se registrou uma significativa emigração para a Argentina, embora muito minoritária em relação a outras regiōes e países da Espanha, e que são estudadas sob uma ótica própria da história econômica, com a combinação de enfoques macro e micro. ${ }^{54}$

De maneira subsidiária, em outras regiões, como é o caso de La Rioja, tem-se promovido, com sorte desigual, o estudo local das dinâmicas migratórias em direção à América, o que tem dado lugar a monografias diversas de valor principalmente descritivo. O que mostra que, no fundo, em boa parte da historiografia espanhola, o tema migratório continuava a ser dependente dos condicionantes herdados das comemoraçôes de 1992, não tendo evoluído, desde então, no que diz respeito à necessária renovação de perspectivas analíticas. ${ }^{55}$

De fato, ainda é muito escassa a comparação interregional, excetuando exemplos localizados. Certamente, a discussão sobre que quadro territorial de análise é o mais idôneo para o estudo da emigração é árdua, não sendo privativa dos estudos migratórios hispânicos. Outras historiografias praticam com profusão a análise regional e (explícita ou implicitamente) o enfoque micro-histórico. O problema, como assinalamos, continua radicado no fato de a proliferação de monografias e estudos regionais na Espanha ter-se dado de maneira espontânea e sem colocar em questão a escala escolhida e predeterminada pela atual divisão administrativa do território espanhol. Quer dizer, sem partir de uma mínima reflexão prévia sobre a seleção da escala territorial de análise, e sem critérios teóricos que a orientassem ou a justificassem, e que fizessem mais rentável o seu aproveitamento.

Desta maneira, tem-se caído habitualmente em uma espécie de "positivismo atomizado", que nada resolve nem nada aposta de novo do um ponto de vista historiográfico, apesar, isso sim, de pôr um maior volume de dados ao dispor dos ousados investigadores que se aventurem a elaborar sínteses de conjunto, inter-regionais, espanholas ou ibéricas. Essa acumulação, porém, não constitui por ela própria um "progresso", 
principalmente quando se faz no âmbito da história profissional e acadêmica, e não — como sucede em outras historiografias europeiasdesde círculos eruditos locais mais ou menos amadores (desde as sociétés savantes francesas até a Landesgeschichte germana).

Igualmente, pode-se colocar em destaque a certa ampliação temática que, desde meados da década de noventa, se tem produzido no campo dos estudos migratórios, produto em parte da incorporação, pelo menos parcial, de historiadores com experiência em outros campos temáticos, que se aproximaram do assunto migratório em várias ocasióes, nele injetando uma considerável dose de "ar fresco". Assim, têm-se abordado temas anteriormente quase inéditos, como as políticas públicas do Estado espanhol no que se refere à questão migratória. ${ }^{56} \mathrm{Da}$ mesma maneira, têm-se renovado algumas perspectivas de análise do associativismo emigrante, embora neste âmbito a enumeração descritiva de centros, periódicos e associações, e dos seus correspondentes diretivos, continuem a ser a tônica dominante com escassas exceções. ${ }^{57}$

Tem-se abordado com renovado impulso e, principalmente, com novos enfoques, a análise do desenvolvimento da mobilização política e social entre as comunidades de emigrantes, questão sobre a qual existiam alguns precedentes nos primeiros anos noventa, centrando-se estas novas contribuições, basicamente, no estudo dos âmbitos de sociabilidade política e das estratégias desenvolvidas na emigração pelos republicanos expatriados no século XIX e começos do XX, como bem cobrem as excelentes contribuições neste sentido de Àngel Duarte. ${ }^{58}$ Cabe destaque, também ao aparecimento e desenvolvimento de identidades nacionais alternativas, opostas à espanhola, entre as comunidades de emigrantes galegos, catalães e bascos, ${ }^{59}$ assim como dos imigrantes canários em Cuba, embora neste caso com enfoques excessivamente lastreados por um positivismo estéril. ${ }^{60}$ Igualmente sobrevive, em alguns autores e núcleos, a ênfase na fonte oral como instrumento privilegiado para chegar-se ao estudo tanto do exílio quanto da emigração, com resultados desiguais: tendencialmente notáveis quando a fonte oral não é empregada de forma exclusiva, mas como maneira de aprofundar, no processo de construção da memória, os imaginários coletivos; mais decepcionantes quando se convertem em fonte única e é empregada de maneira acrítica. Neste caso, raras vezes se obtém mais do que uma reiteração de lugares comuns. ${ }^{61}$

Algumas destas incursões têm originado também a elaboração de novas, embora breves, sínteses sobre a emigração espanhola ultramarina. Apesar 
das suas múltiplas lacunas, principalmente no que diz respeito à não integração da produção sobre (i)migrantes espanhóis gerada nos próprios países de destino, parte da qual não deixa de apresentar utilidade. ${ }^{62}$

III.

Uma questão, até agora, fica pendente. Em que não se avançou? Sintetizando ao máximo, podemos assinalar, em minha opinião, as lacunas existentes sob dois pontos de vista: o temático e o teórico-metodológico.

a) No aspeto temático, ficam ainda grandes lacunas por serem preenchidas. Para assinalar apenas algumas, destacaríamos a emigração para a América no período franquista (quer dizer, posterior a 1939), melhor conhecida contudo para o caso da Argentina, assim como a migração para vários países da Europa central depois de 1955 e a sua interrelação com as tradições migratórias ultramarinas.

Do ponto de vista dos fatores de expulsão, e embora consideremos melhor o influxo dos fatores socioeconômicos macroestruturais e microestruturais, falta-nos incorporar em nossas análises, de modo pormenorizado, questôes como a importância de alguns fatores sociopolíticos nas migraçóes do século XIX e XX: por exemplo, o peso relativo da oposição ao serviço militar (particularmente importante nos decênios de 1910 e 1920); a delimitação do que é emigração política e do que é emigração econômica na onda migratória ultramarina posterior a 1946; ou o influxo real do marco jurídico estatal, do qual conhecemos muito mais o conjunto de disposiçôes legais do que o intrincado processo de aplicação prática das mesmas. ${ }^{63} \mathrm{Da}$ mesma forma, desconhecemos, principalmente, qual foi a eficácia no seu cumprimento - lembremos daquela reflexão de MacDonald sobre a dicotomia entre as lógicas políticoadministrativas "manifestas" da burocracia e as funçōes "latentes" das redes sociais, ou as recentes contribuiçôes de Devoto acerca das dificuldades de aplicação da normativa argentina em matéria de imigração ${ }^{64}$ -, tanto pelas instâncias administrativas quanto pelas lógicas políticas, baseadas, particularmente na Espanha da Restauração (1874-1923), na primazia do clientelismo e na vulnerabilidade existente nas normas como fonte da legitimidade das elites políticas locais, fato que dava lugar a emigrações legais do ponto de vista formal, mas que não cumpriam com os requerimentos exigidos. Mais conhecidas, porém, são as dinâmicas político-administrativas que caracterizaram as migraçóes para a Argentina na época franquista, aspecto esclarecido pelas pesquisas de Maria José 
Fernández Vicente e os apontamentos de autoras como a investigadora argentina Nadia de Cristóforis. ${ }^{65}$

Do ponto de vista dos fatores de atração, sabemos ainda relativamente pouco sobre os efeitos reais das políticas de passagens subsidiadas (principalmente no caso do Brasil), ${ }^{66}$ assim como da difusão do mito da América ou da febre da emigração, como a definiu acertadamente José C. Moya ${ }^{67}$ particularmente através da extensão social de imaginários e estereótipos sobre a América, em parte difundidos pelos retornados. ${ }^{68}$ No que respeita à integração socioprofissional dos emigrantes espanhóis nos países de destino, temos ainda, além dos exemplares estudos do historiador cubano-norteamericano José C. Moya para Buenos Aires, do da argentina Liliana Da Orden para Mar del Plata e mais do galegoargentino Ruy G. Farias para o Sul do Grande Buenos Aires, além de aproximaçôes pontuais para diversos pontos de América, poucas aproximações com base empírica quantitativa e suficientemente representativa das diversas dinâmicas de inserção no mercado de trabalho e padrões de mobilidade social. ${ }^{69}$ Neste aspeto, a historiografia (de maneira geral) continua, ainda, bastante cativa das imagens, indubitavelmente enviesadas, que nos fornecem as associações, as coletividades organizadas de emigrantes, os informes consulares espanhóis e as próprias imagens e estereótipos existentes sobre os emigrantes hispânicos nas sociedades de acolhida, assim como de conclusões obtidas pela aplicação de critérios indutivos.

O exílio republicano espanhol é um campo cada vez mais pesquisado e melhor conhecido, embora o seja mais de um ponto de vista quantitativo e acumulativo do que "qualitativo". No início foram principalmente autores não espanhóis (como a historiadora francesa Genèvieve Dreyfus-Armand e as argentinas Clara Lida e Dora Schwarzstein) os que aplicaram enfoques mais próprios da história social e cultural nas suas análises históricas perspectivas e aportaram visões mais sintéticas, não centradas unicamente em descrições localizadas ou interessadas, apenas, na produção artísticocultural de elites e personalidades, quando não nas conhecidas "prosopografias heróicas" de exilados, mais ou menos ilustres. ${ }^{70}$ No decurso dos últimos anos, porém, aprecia-se claramente uma mudança do interesse pelo exílio, passando os pesquisadores, por um lado, a perguntar-se acerca da interação entre emigrantes "econômicos" e exilados "políticos" e, por outro, acerca das mutaçôes e continuidades entre as diversas culturas políticas republicanas na Espanha e na América. ${ }^{71}$ 
Da mesma maneira, é possível ainda se verificar um avanço muito importante no estudo do retorno da emigração, em que as dispersas contribuiçōes existentes apresentam um certo desequilíbrio entre Galiza, Canárias, Astúrias e o resto de Comunidades Autônomas quanto à densidade de conhecimentos. De outra parte, os esforços neste terreno dirigiram-se principalmente ao estudo das remessas e dos capitais indianos, particularmente na conjuntura de 1898-1900, e em menor escala - com exceção possivelmente dos casos galego e asturiano - ao estudo do influxo social, político e nas mentalidades dos emigrantes retornados da América, os "indianos ou americanos". 72

b) No que se refere aos aspetos metodológicos e teóricos, podemos afirmar que não se fizeram grandes progressos nas direções que Devoto assinalava há alguns anos atrás. Primeiramente, a questão da interdisciplinariedade, onde ainda resta muito por avançar. A Espanha continua a ser um paraíso para os devotos das "mesas separadas", e habitualmente, os escassos colóquios celebrados sobre questóes migratórias e exílio, em que se confrontam especialistas em estudos migratórios procedentes de diferentes campos, não fizeram mais do que certificar que as concepções teóricas e, principalmente os objetivos, são muito diferentes em muitos casos, para se encontrar, até mesmo, um vocabulário conceitual de convergência.

Em termos de complementaridade cronológica também resta um longo caminho por percorrer, embora a realidade, insistentemente, demonstre que o continuum entre a época anterior às migrações ultramarinas maciças e a época colonial é maior do que se pensava. Desta maneira, cadeias "adormecidas"; mobilidade à distância, curta e média, que prepara o caminho ao salto transatlântico; trajetórias de exilados políticos que seguem itinerários migratórios traçados com anterioridade por emigrantes das suas comarcas de origem nos séculos XVII e XVIII; ${ }^{73}$ tradições migratórias cristalizadas, que depois se convertem em definitivas e, de um ponto intermediário, orientam-se a outro lugar (para nos reportarmos a um caso conhecido: de galegos de uma comarca, por exemplo Santa Comba [A Corunha] para Portugal, daqui para o Brasil, concretamente para o Rio de Janeiro, inaugurando uma tradição que sobrevive até a década de 1960, ou da comarca pontevedresa da Terra de Montes a Portugal, e mais tarde ao Brasil, tanto a Baía quanto a São Paulo) $;{ }^{74}$ e um longo etc. Mudam, isso sim, os números e as proporções. A orientação dos estudos sobre migrações na época colonial, contudo, segue atrelada à exploração quase que exclusiva de uma fonte (o Arquivo de Índias de Sevilha) e a enfoques tendencialmente macro, excetuando-se o caso galaico-cantábrico, onde se 
faz um amplo uso de fontes paroquiais e municipais, que não se vê acompanhado ou complementado com a consulta a fontes nominativas (ou de outro tipo) nos países de destino.

Continua amplamente vigente, também, o paradigma neomalthusiano, principalmente em numerosos estudos de história econômica, em enfoques baseados na demografia histórica, e em geral em boa parte dos estudos que têm como objeto a Idade Moderna. É certo, contudo, que enfoques baseados no estudo de redes sociais e estratégias camponesas de pluriatividade e mobilidade, bem como no impacto dos sistemas de herança sobre a dinâmica migratória desde os contextos de saída, deram lugar, com muita maior força, a investigações de âmbito local, comarcal ou regional cuja enumeração resultaria prolixa. $\mathrm{O}$ aporte das perspectivas provenientes da Antropologia Social resulta igualmente decisivo neste tipo de enfoques. Estamos ainda longe, porém, de contarmos, para o caso espanhol, com um trabalho da magnitude e a sutileza analítica de C. B. Brettell para o caso da emigração minhota para o Brasil. ${ }^{75}$

Para o desenvolvimento da perspectiva microssocial e para o melhor conhecimento das cadeias migratórias, contudo, assiste-se na Espanha, durante a década de 1990, a preferência pelo uso da fonte oral em detrimento de outras fontes pessoais, como arquivos privados e, particularmente, arquivos epistolares de emigrantes. Isto apresenta vantagens óbvias, mas inconvenientes igualmente claros. De início, pela desconexão que costuma existir entre o conhecimento e contextualização das estruturas socioeconômicas e a sua relação e interação com a categoria da "experiência" dos sujeitos, que é o que transmitem, principalmente, as chamadas "fontes pessoais", principalmente a fonte oral. Para além disso, tanto ao ser utilizada como método exclusivo quanto como método complementar ao uso de inquéritos mediante formulário (como se tem efetuado no caso de migrações recentes a Europa o a Venezuela), esta última não deixa de apresentar problemas hermenêuticos, para além de possuir evidentes limites temporais, derivando, em determinadas ocasiōes, em um evidente abuso, reduzindo-se a uma mera ilustração descritiva que não faz mais do que confirmar os tópicos que, muitas vezes, os emigrantes constroem sobre sua experiência, para além dos motivos e lógicas que os levaram a emigrar. ${ }^{76}$

O emprego de memórias, de diários, de autobiografias e, nomeadamente, de correspondência emigrante até inícios do século XXI foi na Espanha extraordinariamente reduzido, em comparação com outras 
historiografias europeias e com a norteamericana. É sintomático que a publicação de epistolários, até agora, se limite quase que exclusivamente aos fundos do Arquivo de Índias de Sevilla. Quer dizer, orientados para a época colonial (em especial para o século XVIII), compostos, principalmente, por diversas cartas de chamada de emigrantes residentes nas Índias às suas famílias, sem reunir o epistolário de um único grupo familiar ao longo do tempo. Este é o motivo da limitada utilidade de algumas ediçôes destas fontes, mais de uma vez caracterizadas por um caráter preponderantemente impressionista e descritivo, sem procurar seqüências cronológicas de cartas recebidas ou emitidas por um mesmo grupo familiar emigrante que permitam tirar conclusōes mais dinâmicas. ${ }^{77}$ O mesmo acontece com algumas incursões, certamente bem documentadas, no terreno dos arquivos fotográficos dos emigrantes. ${ }^{78}$

Ao menos com relação à Galiza e Astúrias, contudo, está-se começando a caminhar noutra direção, graças ao trabalho de compilação paciente em arquivos familiares privados de famílias camponesas, e atendendo aos modelos e experiências disponíveis em outros países e historiografias (particularmente, as contribuições de Franco Ramella e Baily no seu clássico One Family, Two Worlds), cujos frutos prometem ter uma razoável continuidade, capaz de consolidar uma já incipiente tradição. ${ }^{79}$ Tradição essa que, certamente, César Yáñez já tinha inaugurado ao Sul dos Pirenéus, com seus estudos centrados, em grande medida, na documentação epistolar de casas comerciais catalãs com membros emigrados da sua própria família, fato que permitia, assim, reconstruir as redes comerciais entre a Catalunha e a América, em uma perspectiva microssocial. ${ }^{80}$ Agora, porém, trata-se de aplicá-la a membros dos estratos sociais subalternos, simples camponeses que se converteram em logistas no Rio de Janeiro, pulperos na Pampa argentina ou operários das Docas de Santos e New York, com dificuldades para exprimir-se por escrito, com a finalidade de captar melhor qual a experiência do emigrante anônimo, e quais os mecanismos de transmissão da informação. Fica, contudo, uma certa divisão e mesmo um incipiente debate metodológico entre os mais preocupados por reconstruir as formas de escrita popular como um objetivo em si mesmo, e portanto, tratam as fontes, com freqüência, de maneira descritiva, ou como vias para estudar os modelos de produção material desses textos; e aqueles que têm preferência por utilizar as cartas, como as autobiografias ou memórias, como instrumentos para analisar o funcionamento das redes microssociais, os mecanismos de transmissão da informação no nível microssocial e as representaçôes do mundo que exprimiam os emigrantes. ${ }^{81}$ 
Finalmente, como já temos assinalado, visões e pesquisas orientadas por perspectivas autenticamente comparativas continuam a estar ausentes do panorama historiográfico espanhol sobre as migrações ultramarinas autênticas. Isto atinge não só há ausência de estudos integradores dos avanços das historiografias migratórias europeias e americanas, mas também do diálogo, muitas vezes ausente, com a vizinha historiografia portuguesa sobre as migraçôes. Igualmente inclui a carência de estudos que façam uma adequada comparação interregional de maneira sistemática, fora de algumas notáveis exceçôes e dos enfoques centrados na escala estatal ${ }^{82}$ fenômeno que não só afeta a historiografia sobre as migraçōes ultramarinas, mas também boa parte dos estudos sociológicos sobre emigração espanhola para a Europa desde a década de 1950.

Certamente, a prolixidade dos estudos regionais e a multiplicação de monografias de reduzido alcance fazem com que, em muitas ocasiōes, seja custosa a elaboração de sínteses equilibradas. Contudo, a superação do medo à síntese que, acertadamente, Carlos Forcadell tem assinalado como uma das características mais surpreendentes da historiografia hispânica, ${ }^{83}$ não deve levar-nos ao extremo contrário: à generalização abusiva e à ignorância das monografias regionais, sob pretexto da sua difícil acessibilidade ou da necessária manutenção de firmes esquemas teóricos, que por serem tão rígidos correm o risco de tornar-se inflexíveis. Para citar um exemplo, não é possível afirmar, como por vezes se faz, que regiōes como a Galiza e Navarra tenham, em comum, fatores de expulsão similares no século XIX e em inícios do XX, por serem zonas de pequena propriedade agrária, sem atentar para as peculiaridades do sistema do foro (permanência de alguns aspectos do Antigo Regime) no primeiro caso, e os diversos tipos de paisagem agrária (casarios, arrendamentos e currais) no segundo, com diferentes tipos, para além disso, de sistemas de herança que condicionam fortemente aqueles fatores de expulsão ou de saída (push). Isso também remete aos quadros de análise espacial que são mais adequados para melhor estudar as dinâmicas de transmissão da informação e da "febre" migratória que, em algumas zonas (Galiza, Astúrias) pode ser a freguesia rural, mas em outras o "lugar" ou a aldeia, muito na dependência do tipo de paisagem agrária e da forma de habitat de que provenham os emigrantes, que são muito diferentes ao longo da geografia ibérica. Esses, em todo o caso, invalidam ou, quando menos, relativizam em muito as categorias em que se divide o fluxo imigrante espanhol, que quase sempre costuma refletir, no caso dos estudos feitos pelas historiografias dos países de recepção, as próprias categorias 
estatísticas da Administração consular espanhola (as províncias) ou as circunscrições territoriais declaradas pelos próprios imigrantes ao chegarem aos países de destino.

O panorama da historiografia migratória hispânica é, em começos da segunda década do século XXI, ambivalente. Certamente, houve uma ampliação das perspectivas de análise. Em toda à parte aparecem grupos e núcleos, não muito bem coordenados, que discutem, entre eles, menos do que deveriam; a perspectiva comparada é escassa, mas não inexistente; o conhecimento de outras historiografias, em especial da norteamericana, da italiana e de algumas latinoamericanas tem avançado notavelmente nos últimos anos, embora sem chegar a ser plenamente satisfatório. Como noutros campos da historiografia espanhola, ${ }^{84}$ contudo, recebem-se ideias oriundas de outras historiografias europeias e da norteamericana, que apenas são reformuladas e adaptadas, o que tem por resultado na dificuldade de se encontrar estudos que aportem um enfoque qualitativamente novo nos estudos migratórios internacionais. ${ }^{85} \mathrm{~A}$ moda dos cultural studies no âmbito dos estudos migratórios e na pesquisa sobre o exílio republicano espanhol apenas tem acrescentado um pouco mais de confusão e nenhuma perspectiva realmente inovadora, para além de originais planejamentos estéticos. ${ }^{86}$ Igualmente, a dispersão geográfica e temática tem sido acompanhada por de peso do enfoque baseado no Estado como unidade territorial de análise e das perspectivas macroestruturais, produzindo-se um aumento equivalente de monografias e títulos centrados em regiōes e localidades específicas. A "institucionite" aguda de que padecem a maioria dos historiadores hispânicos, em muitas ocasiōes, leva-os a publicar os seus resultados em edições institucionais, cuja distribuição é nula, ${ }^{87}$ a agarrar-se a comemorações e encomendas específicas por parte desses mesmos organismos públicos, e a cair no positivismo de que tanto costumam gostar os mercados locais, e ainda mais se esses mercados são também mercados culturais hiperprotegidos por motivos político-linguísticos (como acontece nos casos catalão e galego). É assim que o positivismo também costuma ser uma válvula de escape para contentar os mercados regionais e locais, que procuram principalmente autoafirmação, informação nominativa e acumulativa e respostas rápidas; e não a formulação de novas perguntas e o desenvolvimento de enfoques teóricos inovadores.

Percebem-se, contudo, novas preocupações no novo século. Em boa medida, são muito semelhantes àquelas que percorrem a historiografia migratória italiana. ${ }^{88}$ Por um lado, a mestiçagem. É cada vez mais difícil 
falarmos numa "historiografia" ou 'historiografias espanholas'. É também cada vez mais complicado etiquetar escolas historiográficas em termos nacionais: as discussões são transformacionais, e os enfoques também o são. A colaboração, por exemplo, de especialistas argentinos, brasileiros, mexicanos e norteamericanos em publicações conjuntas com os seus colegas espanhóis (ou galegos, bascos e catalães) é já habitual, tanto nas mesmas revistas quanto nas mesmas monografias. ${ }^{89}$ Além disso, há especialistas latinoamericanos que se formam na Espanha, de igual maneira que os especialistas espanhóis dialogam e incorporam enfoques historiográficos elaborados pelos historiadores latinoamericanos da imigração. Desta maneira, faz cada vez menos sentido falar em historiografias "nacionais" e mesmo "subnacionais", no sentido clássico do termo, mais próprio do século XX que do século XXI.

Por outro lado, verifica-se o interesse por conectar a emigração do passado com a imigração do presente, pelo fato de a Espanha se converter desde 2002 num país de imigração maciça. O fato de muitos desses imigrantes serem descendentes de imigrantes espanhóis na América (isto é, filhos e netos de imigrantes espanhóis na Argentina, no Uruguai ou no Brasil) tem levado uma nova geração de historiadores a se ocupar das similaridades e diferenças entre estas duas ondas, e a relacionar a transmissão familiar da experiência migratória. Os netos experimentam o caminho inverso, com problemas similares àqueles que conheceram os avós setenta ou oitenta anos atrás. ${ }^{90}$ Finalmente, o fato de os chamados "residentes ausentes", isto é, os emigrantes espanhóis no estrangeiro e os seus descendentes que adquiriram ou recuperaram a cidadania espanhola, terem-se convertido num fator de certa influência eleitoral na cena política espanhola dos últimos vinte anos, por terem o direito, conforme a legislação espanhola garante, de exercerem o seu direito ao sufrágio em todo o tipo de eleiçóes (locais, autônomas, estatais e europeias), o que tem implicado, também, o aprofundamento das perspectivas da comunicação política entre a Espanha e as suas coletividades emigrantes. Isto inclui, por sua vez, a análise da influência política e eleitoral dos emigrantes na Espanha do século XX, ${ }^{91}$ mas também a recriação dos projetos políticos espanhóis pelas elites emigrantes (nomeadamente em cidades que concentraram uma grande massa de imigrantes e uma grande densidade de jornais étnicos, como Buenos Aires), e a sua recriação da democracia, do "patriotismo" e da república na distância. ${ }^{92}$ Também em aspectos como este, tende-se a sublinhar, de maneira paralela, como as novas tendências da história transnacional e global estão afirmando, desde há poucos anos, que a 
globalização existia já antes da globalização, e que a História e o percurso das sociedades europeias de emigração foi e é inseparável da evolução das áreas americanas de imigração.

\section{Notas e Referências}

1 Para uma análise do estado da arte até a última década do século XX, vid. nosso artigo "Historiografía española reciente sobre migraciones ultramarinas: Un balance y algunas perspectivas". Estudios Migratorios Latinoamericanos, 48 (2001), pp. 269-95.

2 J. CASANOVA. La historia social y los historiadores. Barcelona: Crítica, 1991, pp. 164-66.

3 A metáfora, aplicada ao campo da ciência política, provém, como é sabido, de G. ALMOND. "Separated Tables". Political Science Review, 21 (1988), pp. 828-42.

4 Os historiadores mexicanos que se ocuparam desta questão, porém, aprofundaram-se muito mais, esse fato foi ajudado pela maior e melhor disponibilidade de fontes nominativas sobre o exílio nesse país. Vid, por exemplo, D. Pla BRUGAT. "Características del exilio en México en 1939”. In: C. E. LIDA (comp.). Una inmigración privilegiada. Comerciantes, empresarios y profesionales españoles en México en los siglos XIX y XX. Madrid: Alianza, 1994, pp. 218-31; id., Els exiliats catalans. Un estudio de la emigración republicana española en México, México D.F.: INAH/Orfeó Català/Libros del Umbral, 1999, e id. (ed.), Pan, trabajo y hogar. El exilio republicano español en América Latina, Mexico: SEGOG-INM-INAHDGE Eds., 2007; igualmente o já clássico C. E. LIDA. Inmigración y exilio. Reflexiones sobre el caso español. Mexico: Siglo XXI/El Colegio de Mexico, 1997. Igualmente, para um ensaio de tipologia dos emigrantes e dos exilados, Cf. X. M. Núñez SEIXAS. "Itinerarios do desterro: Sobre a especificidade do exilio galego de 1936”. In: X. M. Núñez SEIXAS e P. Cagiao VILA (eds.). O exilio galego: Política, sociedade, itinerários. Sada-A Corunha: Eds. do Castro/ Consello da Cultura Galega, 2006, pp. 11-51.

5 Vid. N. Sánchez ALBORNOZ (comp.). Españoles hacia América. La emigración en masa, 1880-1930. Madrid: Alianza, 1988.

6 F. DEVOTO. "En torno a la historiografía reciente sobre las emigraciones española e italiana a Latinoamérica”. Estudios Migratorios Latinoamericanos, 25, 1993, pp. 441-60.

7 Cf M. SANFILIPPO. Problemi di storiografia dell'emigrazione italiana,.Viterbo: Sette Città, 2005 [2a ed.]; E. FRANZINA. "Le risorse dell' etnia e i doni della politica: Approssimazioni sugli italiani americani nella storia politica di un continente". Italia Contemporanea, 217, 1999, pp. 651-66.

8 VV. AA. Historia general de la emigración española a Iberoamérica. Madrid: Historia 16, 1992, 2 vols. 
9 Por exemplo, a coleção Amerika eta Euskaldunak, editada pelo Governo regional basco; a Commissió Catalana del Quint Centenari promoveu a publicação de um Diccionari dels Catalans d'Amèrica em quatro volúmes; a Comisión Galega do Quinto Centenario, constituída já em 1988, promoveu igualmente a publicação de uma revista de vida breve, a Revista da Comisión Galega do Quinto Centenario, e mais tarde o Consello da Cultura Galega organizou uma muito sucedida exposição, Galicia e América: Cinco séculos de Historia, que foi acompanhada pelo catálogo do mesmo nome, publicado em galego, inglês e espanhol.

10 Ver N. TABANERA GARCÍA. "Conmemoración e historiografía: Los estudios sobre emigración española a América Latina en el Quinto Centenario”. Estudios Migratorios Latinoamericanos, 38 , 1998, pp. 3-15.

11 Algo bem patente, principalmente, na aparição de monografias sobre os cántabros ou os riojanos na América, ou até sobre o exílio destas duas Comunidades Autônomas, que não existiam anteriormente mais do que como províncias (Santander e Logroño), sem grande especificidade identitária. De igual maneira, também se estudará, sem problematização prévia da escala de análise, o exílio político cântabro ou valenciano de 1936 na América, sem atentar necessariamente para o fato de que a distribuição regional dos exilados foi motivada, em boa medida, pelo acaso geográfico: aquelas regiões que continuaram sob poder da República em julho-agosto de 1936 proporcionaram, como é lógico, os maiores contingentes de exilados. Vid A. GIRONA e F. MANCEBO (eds.). El exilio valenciano en América: obra y memoria. Valência: Univ. de Valência, 1995. De um ponto de vista metodológico, destaca-se, porém, por sua cuidadosa elaboração e por colocar questôes que até o momento ninguém tinha abordado - como as modalidades de inserção socioprofissional dos exilados e a sua relação com os emigrantes 'económicos' - C. Soldevilla ORIA. La Cantabria del exilio: una emigración olvidada. Santander: Univ. de Cantabria, 1998.

12 Caso, por exemplo, dentro da coleção sufragada pela companhia de seguros Mapfre pelo motivo do Quinto Centenário, dos volumes, de F. J. ASÍN. Aragón y América, Madrid: Mapfre, 1992; de M. CUESTA. Extremadura y América. Madrid: Mapfre, 1992; de M. Ballesteros GAIBROIS. Valencia y América. Madrid: Mapfre, 1992, ou de J. I. Sáenz DÍEZ. Los riojanos en América. Madrid: Mapfre, 1992.

13 Cf., por exemplo, A. García ÁLVAREZ e J. A. Blanco RODRÍGUEZ. Gestión económica y arraigo social de los castellanos en Cuba, Valladolid: Junta de Castilla y León, 2009.

14 Vid. as apreciações de TABANERA. “Conmemoración”. Op. Cit., pp. 7-8.

15 Vid., de outra parte, por exemplo, as exaustivas monografias de R. Márquez Macías. La emigración española a américa (1765-1824)., Oviedo: Universidad de Oviedo, 
1995, E I. Macías domínguez. La llamada del nuevo mundo. La emigración española a América (1701-1750). Sevilha: Universidad de sevilla, 1999.

16 Para uma reflexão sintética sobre esta questão, vid. F. DEVOTO. "As migracións internacionais e a cuestión da escala”. Estudios Migratorios, 3, 1997, pp. 9-34.

17 Para uma panorâmica historiográfica até 2001, vid. D. Pla BRUGAT. "El exilio republicano en Hispanoamérica. Su historia e historiografía”. Historia Social, 42, 2002, pp. 99-121.

18 B. Sánchez ALONSO. Las causas de la emigración española, 1880-1930. Madrid: Alianza, 1995; id., "Those who moved and those who remained. Explaining Emigration from the Regions of Spain, 1880-1914”. The Journal of Economic History, 60: 3, 2000, pp. 732-57.

19 Vid. C. YÁÑEZ. La emigración española a América (siglos XIX y XX). Dimensión y caracteristicas cuantitativas. Colombres: Archivo de Indianos, 1994; id., Sortir de casa per anar a casa. Comerç, navegació i estratègies familiars en l'emigració de Sant Feliu de Guixols a Amèrica en el segle XIX. Sant Feliu de Guixols: Ajuntament, 1992; id., Emigración ultramarina y familia catalana en el siglo XIX. Los Moreu Rabassa de Calella. Mataró: Caixa d'Estalvis Laietana, 1995, e Saltar con red. La temprana emigración catalana a América, ca. 1830-1870. Madrid: Alianza, 1996.

20 Vid., sem sermos exaustivos, J. C. MOYA. Cousins and Strangers. Spanish Immigrantes in Buenos Aires, 1850-1930. Berkeley et al.: Univ. of California Press, 1998; vários das contribuições recolhidas em A. E. FERNÁNDEZ e J. C. MOYA (eds.). La inmigración española en la Argentina. Buenos Aires: Biblos, 1999; C. ZUBILlAGA (ed.), Españoles en el Uruguay. Características demográficas, sociales y económicas de la inmigración masiva. Montevideu: Univ. de la República, 1997, e id. La Utopía Cosmopolita: Tres perspectivas históricas de la inmigración masiva en Uruguay. Montevideu: Universidad de la República, 1998; J. OYAMBURU (coord.), Españoles en Costa Rica. San José: Embajada de España/Centro Cultural Español, 1997; várias das contribuições recolhidas em B. FAUSTO (ed.). Fazer a América. A imigração em massa para a América Latina. São Paulo: Edusp, 2000 [2a ed.], ou VV.AA.. Inmigración española en Chile. Santiago de Chile: Serie Nuevo Mundo, 1994, assim como F. Vejarano ALVARADO, Ma E. Martínez GORROÑO e C. Hoyos URIBE. Memoria y sueños. Españoles en Colombia. Siglo XX, Bogotá: Fundación Españoles en Colombia, 2004, e VV. AA.. Memorias del Primer Congreso sobre la Emigración Española hacia el área del Caribe desde finales del Siglo XIX. Santo Domingo: Fundación García Arévalo, 2002.

21 Vid., por exemplo M. IRIANI. Hacer la América. Los vascos en la Pampa húmeda: Argentina, 1830-1930, Leioa: UPV, 2000; vários das contribuições recolhidas 
em X.M. Núñez SEIXAS (ed.), La Galicia Austral. La inmigración gallega en la Argentina. Buenos Aries: Biblos, 2001. Não contamos aqui os vários estudos sobre coletivos de imigrantes espanhois realizados por historiadores brasileiros, argentinos, uruguaios, mexicanos, etcétera, de Carlos ZUBILLAGA sobre a presença galega no Uruguai, de Rosario S. ALBÁN sobre os galegos na Baía (Brasil), de Marília KLAUMANN sobre os espanhois em São Paulo, e outros mais.

22 Por exemplo, a de B. Sánchez ALONSO. La inmigración española en la Argentina, siglos XIX y XX. Colombres: Archivo de Indianos, 1992.

23 Prova disso é o olhar positivista de G. RUEDA. La emigración contemporánea de españoles a Estados Unidos, 1820-1950. De «Dons» a "Misters". Madrid: Mapfre, 1993.

24 Vid. J. Buades i CRESPÍ et al. Emigrants illencs al Rio de la Plata (la vida associativa a Buenos Aires i Montevideo). Palma de Maiorca: Govern Balear, 1995; ou vários das contribuiçôes recolhidas em VV.AA.. América y Mallorca. Del predescubrimiento hasta el siglo XX. Palma de Maiorca: Ajuntament de Palma, 1991.

25 Concretamente, a monografía da geógrafa argentina A. Jofre CABELLO. Asi emigraron los baleares a la Argentina. Palma de Maiorca: Govern Balear, 1997, assim como alguns trabalhos posteriores desta mesma autora.

26 J. Hernández GARCÍA. La emigración canario-americana en la segunda mitad del siglo XIX. Las Palmas: Cabildo Insular de Gran Canaria, 1981; id., Los canarios en la gestación de la república de Venezuela (1831-1863). Santa Cruz de Tenerife: Centro de la Cultura Popular Canaria, 1982. Vid., também, M. Hernández GONZÁLEZ. Canarias, la emigración: la emigración canaria a América a través de la Historia. Santa Cruz de Tenerife: Centro de la Cultura Popular Canaria, 1995, e id., La emigración canaria a América (1765-1824). Entre el libre comercio y la emancipación. Santa Cruz de Tenerife: Centro de la Cultura Popular Canaria, 1996.

27 Vid. uma síntese já clássica em A. M. Macías HERNÁNDEZ. La migración canaria, 1500-1980. Colombres: Archivo de Indianos, 1992, assim como as atas dos diversos Colóquios de História Canário-Americana, editados pelo Cabildo Insular de Gran Canária.

28 Vid. o interessante estudo local de J. A. Yanes MESA. La emigración del municipio canario de Güimar, 1917-1934. La Laguna: Centro de la Cultura Popular Canaria, 1993.

29 Vid., por exemplo, F. Carnero LORENZO. "Las remesas de los emigrantes canarios en Cuba, 1886-1914”. Historia Contemporánea, 19, 1999, 275-85, e id. J. S. Nuez YANEZ. El papel del capital indiano en la modernización de la 
economía canaria, c. 1852-1936. Las Palmas: Cabildo Insular de Gran Canária, 2009, assim como J. S. Nuez YANEZ. Canarias-Uruguay-Canarias. El papel de los emigrantes canarios en el tejido empresarial de Canarias y Uruguay. Santa Cruz de Tenerife: Ediciones Idea, 2006.

30 J. L. YANES. Las remesas indianas en el Valle de Güimar. Islas Canarias, 18681898, Las Palmas: Anroart, 2010.

31 Em especial, publicística e imprensa emigrante, graças à catalogação dos fundos da Biblioteca América da Biblioteca Universitária de Santiago de Compostela, a microfilmagem de fundos de associações galegas e a adquisição de bases de dados dos países recetores, particularmente da Argentina.

32 CfX. M. Núñez SEIXAS. "History and Collective Memories of Migration in a Land of Migrants: The Case of Iberian Galicia". History and Memory, 14: 1-2, 2002, pp. 229-58.

33 Para além dos seus abundantes artigos, vid. a completa tese de doutoramento do recentemente finado A. Vázquez GONZÁLEZ. "La emigración gallega a América, 1850-1930". Universidade de Santiago de Compostela, 2000, 2 vols. Também é de algum interesse, independentemente da sua brevidade, $\mathrm{M}^{\mathrm{a}}$ X. Rodríguez GALDO. Galicia, país de emigración. Colombres: Archivo de Indianos, 1993.

34 Vid. V. Peña SAAVEDRA. Éxodo, organización comunitaria e intervención escolar. La impronta socioeducativa de la emigración transoceánica en Galicia. Santiago de Compostela: Xunta de Galicia, 1991, 2 vols.. Algumas obras posteriores, comos as de X. M. MALHEIRO. As Escolas dos emigrantes e o pensamento pedagóxico: Ignacio Ares de Parga e Antón Alonso Rios. Sada-A Corunha: Eds. do Castro, 2006, ou id. Herdanza da emigración ultramarina: Catálogo fotográfico da arquitectura escolar indiana na provincia de Pontevedra. Pontevedra: Deputación Provincial, 2005, não acrescentam nada ao já assinalado por outros autores na década de 1990 .

35 Vid. a tese de doutoramento, ainda inédita, de P. Cagiao VILA. "Participación económico-social de la inmigración gallega en Montevideo, 1900-1970". Universidad Complutense de Madrid, 1990; ou E. VILLAVERDE. Galegos en Mexico (1878-1936). Santiago de Compostela: Sotelo Blanco, 2003. Sobre a imigração galega em Porto Rico, vid. X. M. VILLA. "Los Gallegos de Puerto Rico, 1821-1963, un proceso de formación de burguesía a ambos lados del Atlántico". Tese de doutoramento, Universidade de Santiago de Compostela, 2000. Igualmente, os estudos de E. SARMIENTO. "Os galegos no Rio de Janeiro” e R. G. Farías IGLESIAS. “La inmigración gallega en el Sur del Gran Buenos Aires, 1869-1960”. Tese de Doutoramento, Universidade de Santiago de Compostela, 2010. 
36 Vid. os diversos volumes compilados por A. Eiras ROEL, como Aportaciones al estudio de la emigración gallega. Un enfoque comarcal. Santiago de Compostela: Xunta de Galicia, 1991; o mais amplo Emigración española y portuguesa a América. Alicante: Instituto de Cultura Juan Gil Albert, 1991, assim como A. Eiras ROEL e O. Rey CASTELAO (eds.). Migraciones internas y medium-distance en la Península Ibérica, 1500-1900. Santiago de Compostela: Xunta de Galicia/ CIDH, 1994, 3 vols.

37 Vid. R. FARÍAS (comp.). Buenos Aires Gallega. Inmigración, pasado y presente. Buenos Aires: Gobierno Autónomo de la Ciudad de Buenos Aires, 2007, com contribuições de historiadores galegos e argentinos.

38 Seja permitido citar aqui os nossos trabalhos O galeguismo en América, 18791936. Sada-A Corunha: Ed. do Castro, 1992; Emigrantes, caciques e indianos. Vigo: Eds. Xerais, 1998, e O inmigrante imaxinario. Estereotipos, identidades e representacións dos galegos na Arxentina (1880-1940). Santiago de Compostela: USC, 2002. Igualmente, vid. R. Ma LOJO, M. Guidotti de SÁNCHEZ e R. FARÍAS. Los "gallegos" en el imaginario argentino. Literatura, sainete, prensa. A Corunha: Fundación Barrié de la Maza, 2008.

39 Vid. P. Cagiao VILA. Muller e emigración. Santiago de Compostela: Xunta de Galicia, 1997, assim como J. Hernández BORGE e D. González LOPO (eds.). Mujer y emigración: Una perspectiva plural. Santiago de Compostela: USC, 2008, e A. Liñarez GIRAUT (coord.). El protagonismo de la mujer en las corrientes migratorias españolas. Vigo: Grupo España Exterior, 2009.

40 Vid., por exemplo, a síntese de R. VILLARES e M. Fernández SANTIAGO. Historia da emigración galega a América. Santiago de Compostela: Xunta de Galicia, 1996.

41 Cf. R. ANES. La emigración de asturianos a América. Colombres: Archivo de Indianos, 1993.

42 Vid. J. J. RODRÍGUEZ. Asturias y América. Madrid: Mapfre, 1992.

43 Vid. por exemplo F. ERICE. "Los asturianos en Cuba y sus vínculos con Asturias: rasgos y desarrollo de una colectividad regional en la etapa final del colonialismo español”. In: P. Gómez GÓMEZ (coord.). De Asturias a América. Cuba (18501930). La comunidad asturiana de Cuba. s.1. 1996, 71-152, ou, do mesmo autor, "Retorno y retornados de la emigración a América: el caso de Asturias". In: J. Cuesta BUSTILLO (coord.). Retornos (De exilios y migraciones). Madrid: Fundación Largo Caballero, 1999, pp. 39-73.

44 Vid., por exemplo, J. López ÁLVAREZ (ed.). Asturianos en América (18401940). Fotografía y emigración. Gijón: Museo del Pueblo de Asturias, 2000.

45 Vid. O. Alvarez GILA. “De 'América y los vascos' a la 'octava provincia': 20 años de historiografía sobre la emigración y presencia vasca en las Américas (siglos XIX y XX)". Vasconia, 34, 2005, pp. 275-300. 
46 Sobre este tema, e em referência às festas bascas dos EE.UU., deve destacar-se o original trabalho de K. Fernández de LARRINOA. Ospakizuna, errituala eta historia: mendebako urrutiko euskal jaiak antropologiaren harira. Vitoria: Gobierno Vasco, 1992. Igualmente, A. ALONSO e P. J. OIARZABAL (eds.). Diasporas in the New Media Age: Identity, Politics and Community. Reno: Univ. of Nevada Press, 2010, e P. J. OIARZABAL e A. OIARZABAL. La identidad vasca en el mundo. Bilbao: Errorteta, 2005.

47 Para uma panorâmica, vid. (sem pretender-se exaustividade) J. M. Azcona PASTOR. Los paraísos posibles. Historia de la emigración vasca a Argentina y Uruguay en el siglo XIX. Bilbao: Univ. de Deusto, 1992; R. ESCOBEDO et al. (eds.). Euskal Herria y el Nuevo Mundo: La contribución de los vascos a la formación de las Américas. Leioa: UPV/EHU, 1996; id., Emigración y redes sociales de los vascos en América. Leioa: UPV/EHU, 1996; E. Fernández de PINEDO. La emigración vasca a América, siglos XIX y XX. Colombres: Archivo de Indianos, 1993; assim como as sínteses regionais, ainda sob o influxo das comemoraçóes de 1992, de J. A. GALLEGO et al. Navarra y América. Madrid: Mapfre, 1992, pp. 293-455, e E. Ruiz de AZÚA. Vascongadas y América. Madrid: Mapfre, 1992, pp. 265-339. Uma síntese bem atualizada em O. Alvarez GILA. "Las nuevas Euskal Herrias americanas. Los vascos y las emigraciones ultramarinas (1825-1950)".IN: J. AGIRREAZKUENAGA (dir.), La crisis de la civilización de los vascos del Antiguo Régimen y estrategias de revolución liberal e industrial: 1789-1876. San Sebastián: Lur, 2005, pp. 319-91.

48 Vid, por exemplo, o volume coletivo de S. FERNÁNDEZ e G. Dalla CORTE (coord.). Sobre viajeros, intelectuales y empresarios catalanes en la Argentina. Tarragona: UNR/Medamérica/Cealc/UB, 1998, ou os diversos trabalhos de Alejandro FERNÁNDEZ, intitulado Un 'mercado étnico' en el Plata: Emigración y exportaciones españolas a la Argentina, 1880-1935. Madrid: CSIC, 2004.

49 Por exemplo, M. Morales MONTOYA. La Generalitat de Josep Irla i l'exili polític català. Barcelona: Base, 2008.

50 Por exemplo, o notável estudo local de Ll. COSTA. L'illa dels somnis. L'emigració de Begur a Cuba al segle XIX. Begur: Ajuntament de Begur, 1999.

51 Vid., por exemplo C. Soldevilla ORIA. Cantabria y América. Madrid: Mapfre, 1992, e id., La emigración de Cantabria a América. Hombres, mercaderías y capitales. Santander: Ayto. de Santander/Ed. Tantín, 1997.

52 J. B. VILAR. Los murcianos y América, Madrid: Mapfre, 1992, pp. 387-433; id.. Las emigraciones murcianas contemporáneas. Murcia: Universidad de Murcia, 1999.

53 Vid., dentre outros J. A. Blanco RODRÍGUEZ (ed.). Zamora y Castilla y León en las migraciones españolas, Zamora: Diputación de Zamora / UNED, 2003; 
id. (ed.), El sueño de muchos. La emigración castellana y leonesa a América, Zamora: Diputación de Zamora / UNED, 2005.

54 Vid. uma boa síntese em E. Fernández CLEMENTE e V. Pinilla NAVARRO. Los aragoneses en América (siglos XIX y XX). I. La emigración, Zaragoza: Gobierno de Aragón, 2003, 2 vols.

55 Vid., por exemplo P. A. Gurria GARCÍA e M. Lázaro RUIZ. Tener un tío en América. La emigración riojana a Ultramar (1880-1936), Logroño: Instituto de Estudios Riojanos / Gobierno de La Rioja, 2002; A. Salvador RUIZ. Emigración riojana a Mexico. Siglo XX. Logroño: Instituto de Estudios Riojanos / Gobierno de La Rioja, 2002.

56 Vid., no que tange a este assunto, vários dos artigos de N. TABANERA, como "La política migratoria española entre la dictadura y la República (1923-1936)", Exils et Migrations Ibériques au XXe siécle, 7, 1999, pp. 73-93 e de Ma J. Fernández VICENTE, como "En busca de la legitimidad perdida. La política de emigración del régimen franquista, 1946-1965”. Estudios Migratorios Latinoamericanos, 56 (2005) pp. 3-30.

57 Vid., por exemplo várias das contribuições recolhidas em Gómez GÓMEZ (coord.). De Asturias a América. Cuba (1850-1930). De alguma riqueza em dados, mas de decimonónico positivismo, são outros trabalhos cuja maior contribuição é elaborar inventários de associaçōes de emigrantes e descrições das suas atividades. Vid., por exemplo, M. LLORDEN MIÑAMBRES. "Las asociaciones de inmigrantes españoles en América. Algunas respuestas a los desequilibrios y carencias de la emigración a ultramar". Exils et Migrations Ibériques au XXe Siècle, 5, 1998, pp. 79-129, assim como J. A. Blanco RODRÍGUEZ. "Emigración y asociacionismo castellano y leonés en América". Alcores, 1, 2006, pp. 169-206; a mesma focagem descritiva pode apreciar-se em várias das compilações mais recentes sobre o tema, como demonstram algumas das contribuiçôes recolhidas em J. A. Blanco RODRÍGUEZ (ed.). El asociacionismo en la emigración española a América Zamora: UNED, 2008.

58 A. DUARTE. La República del Emigrante. La cultura politica de los emigrantes españoles en Argentina (1875-1910). Lleida: Milenio, 1998; id., "A patria lonxe da casa. Emigración política e identidade nacional dos españois en Arxentina (ca. 1880-ca. 1914". Estudos Migratorios, 9, 2000, pp. 33-59.

59 Sem vontade de ser exaustivo, vid. O. Álvarez GILA. “'Vascos y vascongados': Luchas ideológicas entre carlistas y nacionalistas en los Centros Vascos del Río de la Plata (1900-1930)". In: R. Escobedo MANSILLA, A. de Zaballa BEASCOECHEA e O. Álvarez GILA (eds.). Emigración y redes sociales de los vascos en América. Leioa: UPV/EHU, 1996, 171-92, ou id., "Clero vasco y nacionalismo: del exilio al liderazgo de la emigración (1900-1940)". Studi Emigrazione/Migration Studies, XXXVI:133, 1999, pp. 103-18. Como tentativa 
de uma visão sintética, vid. X. M. Núñez SEIXAS. "Leadership ethnique, exil politique et ethnonationalisme chez les collectivités ibériques en Amérique Latine (1880-1960)". In: F. DEVOTO e P. GONZÁLEZ-BERNALDO (eds.). Émigration politique. Une perspective comparée. Italiens et Espagnols en Argentine et en France (XIXe - Xxe siècles). París: L'Harmattan/CEMLA, 2001, pp. 263-94.

60 Por exemplo, G. J. Cabrera DÉNIZ. Canarios en Cuba: Un capitulo en la historia del archipiélago (1875-1931). Las Palmas: Cabildo Insular de Gran Canaria, 1996.

61 Sem qualquer dúvida, quando a fonte oral é empregada de maneira complementar e não autossuficiente, os resultados são mais do que apreciáveis. Vid., por exemplo P. Cagiao VILA. "A vida cotiá dos emigrantes galegos en América”. In: id. (comp.), Galegos en América e Americanos en Galicia. Santiago de Compostela: Xunta de Galicia, 1999, pp. 115-35.

62 É o caso, em minha opinião, de G. Rueda HERNANZ. Emigrantes españoles en América (siglos XVI-XX). Madrid: Arcolibros, 2000. Vid., também, J. B. VILAR. La España del exilio. Madrid: Síntesis, 2006, obra que acusa similares carências.

63 Quanto às normas legais no século XIX e XX, vid., exaustivamente, J. M. PÉREZ-PRENDES. El marco legal de la emigración española en el Constitucionalismo. Colombres: Archivo de Indianos, 1993.

64 Vid. J. S. MACDONALD. "Italian Migration to Australia. Manifest Functions of Bureaucracy versus Latent Functions of Informal Networks". Journal of Social History, 3:3, 1970, pp. 249-75.

65 Ma J. Fernández VICENTE. Émigrer sous Franco. Politiques publiques et stratégies individuelles dans l'émigration espagnole vers l'Argentine et vers la France (19451965). Lille: ANRT, 2004.

66 Para além de E. González MARTÍNEZ. Cafée inmigración: los españoles en São Paulo, 1880-1930. Madrid: CEDEAL, 1990, vid., também, A. Vázquez GONZÁLEZ. "La reducida aportación gallega a la agricultura americana, 18301936: Una interpretación”, em Fernández Y Moya, La emigración española, pp.71-93. Muito menos satisfatório é R. E. dos SANTOS. Política migratoria española a Iberoamérica, aporte Brasil a través de los informes consulares en el periodo 1890-1950. Sada-A Corunha: Eds. do Castro, 1996.

67 Vid. J.C. MOYA. "La "fiebre” de la emigración: El proceso de difusión en el éxodo transatlántico español, 1850-1930". In: FERNÁNDEZ e MOYA (eds.). La inmigración española, Op. Cit. pp. 19-41.

68 Uma tentativa de aproximação à questão no nosso artigo "Una aproximación a la imagen social del emigrante retornado de América en la Península Ibérica (siglos XVI-XX)”. In: Cuesta BUSTILLO (coord.). Retornos, Op.Cit., pp. 3-38.

69 Exceçôes mais ou menos relativas podem ser J. Maluquer de MOTES. Nación e inmigración: los españoles en Cuba (ss. XIX y XX). Colombres: Archivo de 
Indianos, 1992 ou, para o caso cubano, J. A. VIDAL. La emigración gallega a Cuba: trayectos migratorios, inserción y movilidad laboral, 1898-1968. Madrid: CSIC, 2005, e id., A Galicia antillana: Formación e destrución da identidade galega en Cuba, 1899-1968. A Corunha: Fundación Pedro Barrié de la Maza, 2008.

70 Vid. G. DREYFUS-ARMAND. El exilio de los republicanos españoles en Francia. De la Guerra Civil a la muerte de Franco. Barcelona: Crítica, 2000 [París 1999]; LIDA. Inmigración y exilio, ou D. SCHWARZSTEIN, Entre Franco y Perón. Memoria e identidad del exilio republicano español en la Argentina. Barcelona: Crítica, 2001.

$71 \mathrm{Vid}$. A. DUARTE. El otoño de un ideal. El republicanismo histórico español y su declive en el exilio de 1939. Madrid: Alianza, 2009; B. ORTUÑO. "El exilio y la emigración española de posguerra en Buenos Aires, 1936-1956". Tese de doutoramento, Universidad de Alicante, 2010; J. de Hoyos PUENTE. "Días del destierro: Las conmemoraciones y aniversarios del exilio republicano en Mexico". Alcores, 7, 2009, pp. 261-89.

72 Vid. a monografia sobre emigração do retorno de Estudios Migratorios, 11-12, 2001. Algumas perspetivas bibliográficas, também, em J. B. VILAR et al. Migración de retorno desde Europa: Su incidencia en la modernización de la región de Murcia (1975-2005). Murcia: Universidad de Murcia, 2008.

73 Vid., no que tange a exemplos para os emigrantes de Cantábria em Soldevilla, La Cantabria, 174-80; para os galegos, temos desenvolvido em profundidade esta questão em "Itinerarios do desterro". Op. cit., assim como em X. M. Núñez SEIXAS e R. FARÍAS. "Transterrados y emigrados: Una interpretación sociopolítica del exilio gallego de 1936". Arbor. Ciencia, Pensamiento y Cultura, 735, 2009, pp. 113-27.

74 Vid., por exemplo E. SARMIENTO. “Os galegos no Rio de Janeiro", e id. $O$ outro río: A emigración galega a Rio de Xaneiro. Santa Comba: TresCTres, 2006.

75 Vid. C. B. BRETTELL. Homens que partem, mulheres que esperam. Consequências da emigração numa freguesia minhota. Lisboa: Dom Quixote, 1991.

76 Exemplos de abuso descritivo-ilustrativo da fonte oral, para citarmos alguns exemplos, podem ser encontrados em C. Samuelle LAMELA. La emigración gallega al Río de la Plata. Santiago de Compostela: Xunta de Galicia, 2001; Ma D. Pérez MURILLO (coord.). Oralidad e historias de vida de la emigración andaluza hacia América Latina (Brasily Argentina) en el siglo XX. Cádiz: Univ. de Cádiz, 2000; G. Alvarez SILVAR. La migración de retorno en Galicia. Santiago de Compostela: Xunta de Galicia, 1997, e id. De volta ao lar, Sada: Eds. do Castro, 2001.

77 Vid., dentre outros, E. OTTE. Cartas privadas de emigrantes a Indias, 15401616. Sevilha: Junta de Andalucía, 1988; F. Morales PADRÓN. Primeras cartas 
sobre América (1493-1503). Sevilha: Univ. de Sevilla, 1990; id. e I. MACÍAS. Cartas de América, Sevilha: Univ. de Sevilla, 1991; R. Márquez MACÍAS. Historias de América. La emigración española en tinta y papel. Huelva: Ertoil, 1994, y J. Ma Usunáriz GARAYOA. Una visión de la América del XVIII: Correspondencia de emigrantes guipuzcoanos y navarros. Madrid: Mapfre, 1992. Mais decepcionante é Ma D. Pérez MURILLO. Cartas de emigrantes escritas desde Cuba: Estudio de las mentalidades y valores en el siglo XIX. Sevilla/Cádiz: Aconcagua/Univ. de Cádiz, 1999.

78 Vid,. por exemplo López ÁLVAREZ (ed.). Asturianos en América (1840-1940). Igualmente, a obra coletiva De la España que emigra a la España que acoge. Madrid: Fundación Largo Caballero, 2006.

79 Vid. R. SOUTELO. Cartas de América. Correspondencia familiar de emigrantes galegos en Uruguai, Brasil, Arxentina e Venezuela, 1914-1964. Santiago de Compostela: Consello da Cultura Galega, 2001, ou J. López ÁLVAREZ. "Cartas desde América. La emigración de asturianos a través de la correspondencia, 1864-1925”. Revista de Dialectología y Tradiciones Populares, LV:1, 2000, 81-120; X. M. Núñez SEIXAS e R. SOUTELO. As cartas do destino. Unha familia galega entre dous mundos, 1919-1971. Vigo: Galaxia, 2005.

80 YÁÑEZ. Emigración ultramarina, 35-40 e ss.

81 Alguns desses problemas são abordados, para o caso galego, em X. M. Núñez SEIXAS. "Otras miradas a la historia de la emigración gallega: Sobre cartas, memorias y fotos". Estudios Migratorios Latinoamericanos. Buenos Aires, 58 (2005), pp. 483-503. Vid., também, X. M. Núñez SEIXAS e D. González LOPO (eds.). Amarras de tinta. Emigración transoceánica e escrita popular na Peninsula ibérica, séculos XIX-XX. Santiago de Compostela: Consello da Cultura Galega, 2010 (no prelo).

82 Por exemplo, A. Vázquez GONZÁLEZ. "Coordenadas de la emigración gallega a América: Un estudio comparativo", e A. EIRAS. "Sobre las motivaciones de la emigración gallega a América y otros aspectos. Un enfoque comparativo”. Revista da Comisión Galega do Quinto Centenario, 2, 1989, pp. 15-36 e 57-71.

83 C. FORCADELL. "La fragmentación espacial en la historiografía contemporánea: La historia regional-local y el temor a la síntesis”. Studia Historica. Historia Contemporánea, 13-14, 1995-96, pp. 15-27.

84 M. Pérez LEDESMA. "Historia Social e Historia Cultural (sobre algunas publicaciones recentes)", Cuadernos de Historia Contemporánea, 30, 2008, pp. $227-48$.

85 Isto não impede que por vezes se encontrem interessantes reflexões. Cf. por exemplo J. Silvestre RODRÍGUEZ. "Aproximaciones teóricas a los movimientos migratorios contemporáneos: un estado de la cuestión”. Historia Agraria, 21, 2000, pp. 157-92, ou E. Ramírez GOICOECHEA. Etnicidad, identidady 
migraciones: Teorías, conceptos y experiencias. Madrid: Centro de Estudios Ramón Areces, 2007.

86 Para citar um exemplo, veja-se E. ROMERO. "Amusement Parks, Bagpipes, and Cemeteries: Fantastic Spaces of Galician Identity through Emigration". Journal of Spanish Cultural Studies, 7:2, 2006, pp. 155-69. Também A. Corbacho QUINTELA. "A aculturaçâo e os galegos do Brasil: O vazio galeguista". Tese de doutoramento, Universidade de Santiago de Compostela, 2009.

$87 \mathrm{E}$, por conseguinte, o acesso às publicações editadas em algumas regiões, não por instituições de outras Comunidades Autônomas, mas até a livros editados pelo próprio Governo da regiāo autônoma, Diputación ou Câmara Municipal, é extraordinariamente dificultoso em algumas ocasióes.

88 SANFILIPPO. Problemi, pp. 329-42.

89 Uma boa amostra pode ser a frutífera colaboração entre historiadores bascos da Espanha e da França, e historiadores norteamericanos e latinoamericanos de origem basca, ou especialistas no estudo da emigração basca, que deu lugar aos vários volumes da coleção Urazandi, editada pelo Governo Basco entre 2006 e 2009, e onde se aborda a história de vários centros de emigrantes bascos na América Latina e à presença basca em países como Uruguai, Argentina, México, New York, etc.

90 Por exemplo, os trabalhos de S. SCHMIDT. "De Argentina a España: historias vividas e intercambios imaginados en las migraciones recientes”. Tese de Doutoramento, Universidad de Salamanca, 2009, (retirar essa vírgula) ; E. González MARTÍNEZ. "Redes sociales y emigración: El caso de los marplatenses". Revista de Indias, 245, 2009, pp. 199-224; id. e A. Merino HERNANDO. Historias de acá. La trayectoria migratoria de los argentinos en España. Madrid: CSIC, 2007; B. Sánchez ALONSO. “Argentina y España: Siglo y medio de intercambios migratorios". In: D. S. REHER e M. REQUENA (eds.). Las múltiples caras de la inmigración en España. Madrid: Alianza, 2009, pp. 77-116,

91 Cf. A. LUGILDE. O voto emigrante. Viaxe pola zona escura da democracia española. Vigo: Galaxia, 2007.

92 Vid. M. García SEBASTIANI (ed.). Patriotas entre naciones. Elites emigrantes españolas en Argentina (1870-1940). Madrid: Ed. Complutense, 2010; VV. AA. Ciudadanos españoles en el mundo, Vigo: Grupo España Exterior, 2008. 